\title{
“Dr. B R Ambedkar's Impact on Dalit Rights"
}

\author{
Dr. Hanumanthappa D. G* \\ Assistant Professor, Dept. of Studies and Research in Political Science, Rani Channamma University, Vidy \\ Sangama, Belagavi-591156, Karnataka-India
}

*Corresponding Author: Dr. Hanumanthappa D. G, Assistant Professor, Dept. of Studies and Research in Political Science, Rani Channamma University, Vidy Sangama, Belagavi-591156, KarnatakaIndia

\begin{abstract}
The basic obstacle that stands in the way of India's unfettered equality. To the west, which considers fundamental human rights to be intrinsic, Brahmanism and the social order are largely unidentified. Human rights are the approved result of the system, which is a social framework. The human rights problem that drew Ambedkar's attention in India might be better understood as Ambedkarism, a social solution for the caste-ridden, sick Indian social system. In order to embrace human rights as a part of life to institute fair social order, a series of strategies companionable with Indian condition are predicted; as utilised by Dr Ambedkar himself.
\end{abstract}

Keywords: Ambedkar, Human Rights, egalitarianism, Indian context, social order.

\section{INTRODUCTION}

India has played a key role in establishing the foundations of human rights. With the achievement of autonomy, the most extensive declaration of rights in the world was incorporated into the new Constitution. India has made the most sincere efforts in the world to defend and promote human rights, and it is the champion of human rights.

Not only has India's Constitution featured a complex Bill of Rights, but attempts have also been made to interpret it accurately. (Shreekrishna, 2018)

As everyone knows, Ambedkar's social, economic, and political philosophy is based on everlasting dignified principles that always stand for poignant bond, build a well-built nation by pattering human and fabric resources for the manufacture of merchandise and services for the equitable sharing among the various sections of society.

Such moral and principled forces always stand against all cruel features such as inequality and discrimination, which are especially rampant in Hindu society in India.

Ambedkar's fundamental principles are liberty, equality, fraternity, and social justice.

Ambedkar did not mention human rights as a discipline. Instead, it grew over time and was reflected in his speeches, memorandums, and activities, among other things, as it grew in speed and strength. He believes that these ideas come from great historical thinkers and pragmatists such as Lord Buddha, Kabir, and Phule. None of these radical philosophers are members of the society that Ambedkar was a part of his brilliant views were partly due to the process of socialization he received from his family, which instilled in him a sense of regard for others and a desire to emulate Kabir, the great saint. A book on Lord Buddha given to him by a teacher had a huge influence on his school experience. (Hanumanthappa, 2018)

This shows that Dr. Ambedkar's search for noble and humanistic concepts and ways to liberate people from their long-standing sufferings and oppression was not ethnocentric, as some Brahmanical privileged sectors of society propagate and restrict him to Dalits.

Many people still refer to him as a Dalit leader, despite the fact that, according to his first meeting of oppressed Castes in 1927, his ultimate purpose and aspirations were to acquire manhood or universal humanity and fraternity (Ambedkar, 1990). Several like-minded higher castes were also the backbone of Dr. Ambedkar's efforts, which was rather intriguing. Some of them even took over the management 
of the organisation and weekly papers like Janata Weekly. The ultimate goal was to convert to the Buddha Dhamma, which unites all of the fundamental values of equality, liberty, and fraternity to create an enlightened India.

According to Ambedkar, this is distinct from religion.

Dr. Ambedkar needed about 20 years to convert to Buddhism in 1956 because he had to research global faiths, examine them, and choose the finest one that was extra-scientific and viable. There are also claims that, despite his scientific approach and westernisation, Dr. Ambedkar favoured an exclusively indigenous system of religion, Buddhism, over all other forms of devotion and solely respected Indian culture.

It is important to understand that while Dr. Ambedkar was not entirely western, he was scientific.

He was constantly critical of a wide range of religious scriptures, both western and oriental, and eventually came to the conclusion that Buddhism was the best religion to adopt because of the inherent basic principles that it contained for any healthy society.

As a result, his evaluation framework was comprehensive and incorporated everlasting principles that were necessary of all living creatures. Dr. Ambedkar's commitment to human rights is evident in all of his writings and speeches, memorandums submitted to various committees, and, above all, as the architect of fundamental rights, minorities' rights, socio-economic rights in the form of Directive Principles of State Policy, and special safeguards for the welfare of the weaker sections of society.

He did not subscribe to the notion of Natural Rights.

The ethical theory of rights is based on the notion of rights. (Hanumanthappa, 2018) Special safeguards are desirable because the depressed classes cannot be safeguarded and elevated without them. Some of the measures he proposed for the Dalits' social, political, and educational advancement.

Due to the Poona Pact, his fight for a distinct electorate was unsuccessful.

Due to the incitement of Hindu extremist menfolk, his historic progressive initiative, the Hindu Code Bill, for the protection and development of Hindu women was rejected by legislators and women themselves on the street.

This bill was a watershed moment in making society more compassionate and reducing gender disparities. When the law failed to pass, Dr. Ambedkar resigned from the Ministry of Law in protest of the fundamentalists and in support of the rights of Hindu women, who, like Dalits in India, were oppressed. The Ambedkar viewpoint, often known as Ambedkarism, is still alive and well in India today.

Though it developed gradually and without the purpose of academic endeavors or a discipline, the viewpoint satisfies the standards of the universal concept of human rights, ensuring that people are secure, civilized, and developed both morally and materially.

Dr. B. R. Ambedkar was a visionary when it came to the upliftment of Dalits. His major goal was to eradicate the evil of the deep-seated caste system, instill dignity among the higher castes, and change the country from an uncivilized to a civilized one. While drafting the constitution, he made every effort to ensure that Dalits and women had equal access to rights in the established state.

In India, we can now discover vibrations for impoverished groups. Untouchability has decreased, and their socioeconomic and political standing has increased considerably. Dalits have now emerged as a political force in India, with greater access to education and economic benefits than in the past. Participation in democratic processes has energised people's political consciousness.

The government is also making a serious effort in this area. Efforts to eradicate various discriminatory practises that have infected the system are still ongoing. Dalits' status in high caste society has also improved.

Today, Dalits and non-Dalits share the same tea, stall, hotel, and cinema hall, thanks to Dr. Ambedkar's immaculate, honest, and compassionate efforts. Still, not all is good; caste prejudice may be seen in offices, institutions, and rituals, among other places. The most absurd thing is that our country's authorities lack the will to put the constitution into action. We primarily discover a glaring 
flaw in prophesying and focusing on the past of Indian political fabric. Manu engulfed India's caste system.

In India, Dr. Ambedkar established the caste elimination system. Manu was revered by Hindu orthodoxy in India. Dalits and women, as adorned by Ambedkar, represent India's development and prosperity. Ambedkar astonished Manu by including numerous clauses in his Constitution. By skilfully placing specific clauses into the constitution, Ambedkar was able to successfully deal with Hindu orthodoxy's thought, attitude, and conduct. (Hanumanthappa, 2018)

The Dalit movements across the country are built on similar ideas of liberty, equality, and fraternity, but with varying degrees of intensity and power. When the Amrutnak, a military courtier at the court of the Muslim monarch of Bidar, was given a unique service, he declined it and demanded fifty-two rights for his people instead.

Similarly, when the Indian government refused to implement the Mandal Commission's recommendations, numerous Dalit organisations, notably the Dalit Sangharsha Samiti (DSS) in Karnataka, staged protests and filed memorandums demanding prompt action. Many people are aware that the Mandal commissions' recommendations were intended to help those from the Other Backward Classes (OBCs).

This is the narrative of the Dalits and their movements, who have always stood for principles and have been battling and networking with other like-minded individuals and groups to rebuild society based on shared values and principles.

As a result, every organization founded by Dalits, whether in the name of a leader or a set of ideals, stands for kinship, which contributes to national integration. As a result, no Dalit groups can be considered communal. (Hanumanthappa, 2018)

However, any group or movement founded in the name of caste that attempts to strengthen the existing caste system and poses a threat to the development of a strong nation and equal society, in other words, enlightened India, may be outlawed.

\section{CONCLUSiON}

Dr. B.R. Ambedkar was a major leader in the field of human rights. who, in my opinion, is the greatest Indian of the millennium, was a warrior for human rights not just for the most oppressed segment of the Dalit community, but for all Indian caste-based groups, including workers, farmers, and women.

In the twentieth century, he was India's most prominent human rights crusader. He is a real advocate of human rights, an emancipator, scholar, and remarkable social reformer. In the Indian constitution, he guarantees equal rights to all citizens. (Lajwantsingh, 2016) However, caste propagation and untouchability continue to play detrimental roles in various sectors of society.

Untouchability is a crime against humanity, and India's constitution ensures that all people are treated equally. Our country is confronted with a variety of socioeconomic, educational, and political ills, and the only way to solve them is for the constitution to be effectively implemented in its true spirit. To keep up with the rest of society, Dalits will have to step up and work hard in all areas of social, economic, educational, and political life.

\section{REFERENCES}

[1] Bharati, A.K. (2001). Dr. Ambedkar's Vision for Dalit Upliftment: Extract from a Souvenir. National Conference on Dalit Organizations, New Delhi. Centre for Alternative Dalit Media (CADAM), Delhi.

[2] Charanjit Singh, M. N. (2008). Concept of Human Rights and the Indian Constitution. In B. Sehgal, Human Rights in India Problems and Perspectives (pp. 288-296). New Delhi: Deep and Deep Publications Pvt Ltd.

[3] Dr.Hanumanthappa. D G. (2018). "Relevance of Ambedkar's Contributions to Dalits and Women. International Journal of Research in Humanities and Social Studies, 5 (6), 56-58.

[4] Hanumanthappa. (2018). "Relevance of Ambedkar's Contributions to Dalits and Women". International Journal of Research in Humanities and Social Studies, 5 (6), 56-58.

[5] Lajwantsingh. (2016). IMPACT OF DR. B. R. AMBEDKAR MOVEMENT. International Journal of Current Research and Modern Education (IJCRME), 1 (1), 118-123. 
[6] Shreekrishna. (2018). Dr B. R. Ambedkar's Perception of Human Rights: Methods and Approaches. Journal Of Humanities And Social Science (IOSR-JHSS), 23, (Issue 10,), 4-9.

Citation: Dr. Hanumanthappa D. G. “Dr. B R Ambedkar's Impact on Dalit Rights” International Journal of Political Science (IJPS), vol 7, no.2, 2021, pp. 9-12. doi: https://doi.org/10.20431/2454-9452.0702003.

Copyright: (c) 2021 Authors. This is an open-access article distributed under the terms of the Creative Commons Attribution License, which permits unrestricted use, distribution, and reproduction in any medium, provided the original author and source are credited. 